\title{
INCIDENTAL DIAGNOSIS OF RIGHT VENTRICULAR MYXOMA: IMAGING FINDINGS OF A CASE REPORT WITH A BRIEF REVIEW OF THE LITERATURE
}

\author{
Silvio-Adrian Lopera-Fernandez1 , Alexela-Nerey Mendoza-Aguilar2, \\ Maria del Carmen Garcia-Blanco', Ernesto Roldan-Valadez²,3
}

ardiac myxomas are the most common benign tumours in adults, with an incidence of 0.5 cases per million people per year, $75 \%$ of myxomas occur in females, and 15 to $20 \%$ located in the right atrium. Because their clinical presentation is variable, they are known as "great simulators" of the cardiac nosology. The primary clinical manifestations reported include asthenia, weight loss, fever, palpitations, dyspnea, syncope, and a heart murmur. They can produce lethal complications such as the formation of emboli, which can migrate and cause pulmonary thromboembolism, deep vein thrombosis and arrhythmias. We report a case of a male patient admitted in the emergency room with acute abdominal syndrome in whom the diagnosis of right ventricular myxoma had been not identified until his symptoms progressed to cardiac failure; we discussed the clinical and imaging (MSCT, MRI, and transthoracic ultrasound) findings of this entity with a brief review of the literature.

Keywords: cardiac ventricle; myxoma; right ventricle; thrombus; cardiac tumour.

Corresponding author: Ernesto Roldan-Valadez, e-mail: ernest.roldan@usa.net

1 - Department of Radiology, Hospital General de Mexico "Dr Eduardo Liceaga".

Mexico City, Mexico. 2 - Directorate of Research, Hospital General de Mexico "Dr Eduardo Liceaga".

Mexico City, Mexico. 3 - I.M. Sechenov First Moscow State Medical University (Sechenov University), Department of Radiology.

Moscow, Russia.

For citation: Silvio-Adrian Lopera-Fernandez, Alexela-Nerey Mendoza-Aguilar, Maria del Carmen Garcia-Blanco, Ernesto Roldan-Valadez. Incidental diagnosis of right ventricular myxoma: imaging findings of a case report with a brief review of the literature. REJR 2020; 1O(1):245-251. DOI: 10.21569/2222-7415-2020-10-1-245-251.

Received: $\quad 27.08 .19 \quad$ Accepted: $\quad 28.10 .19$

\section{САУЧАЙНАЯ НАХОАКА - МИКСОМА ПРАВОГО ЖЕАУАОЧКА: КАИНИЧЕСКИЙ САУЧАЙ С КРАТКИМ ОБЗОРОМ АИТЕРАТУРЫ}

\section{Си^ьвио-Алриан ^опера-Фернанлес' , Алексея-Нерей Мендоса-Аги^ар2, Мария дель Кармен Гарсия-Б^анко', Эрнесто Ро^Аан-Ва^алес 2,3}

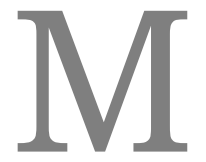

иксомы сердца являются наиболее распространенными доброкачественными опухолями у взрослых, с частотой встречаемости 0,5 случаев на мимлион человек в год, 75\% миксом встречаются у женщин, от $15 \%$ до 20\% расположены в правом предсердии. Поскольку их клиническая картина неоднозначна, они известны как "симуляторы" заболеваний сердца. Первичные клинические проявления вкцючают в себя астению, потерю веса, михорадку, сердцебиение, одышку, обмороки и шум в сердце. Миксомы могут вызывать такие метальные осложнения как тромбоэмбомия мегочной артерии, тромбоз глубоких вен и аритмии.

Мы приводим кАинический случай пациента мужского пола, который поступиц в отделение неотложной помощи с острым абдоминальным синдромом, диагноз миксомы правого желудочка не был установлен до тех пор, пока симптомы не прогрессировали до сердечной недостаточности. В статье освещаются клинические симптомы и данные методов визуализации (МСКТ, МРТ и трансторакальное умьтразвуковое исследование) данной патологии, а также представцен краткий обзор митературы.
1 - Отдемение мучевой диагностики, Больница общего профиля в Мексике "Доктор Эдуардо \ицеага".

Мехико, Мексика.

2 - Научно-

исследовательский отдем, Больница общего профиля Мексики "Доктор Эдуардо $\Lambda$ ицеага".

Мехико, Мексика. 3 - Сеченовский Университет.

Москва, Россия. 
Ключевые слова: желудочек сердца, миксомы, правый желудочек, тромб, опухоль сердца.

Контактный автор: Эрнесто Роланд-Валадез, e-mail: ernest.roldan@usa.net

Для иитирования: Сильвио-Адриан Аопера-Фернандес, Алексея-Нерей МендосаАгилар, Мария дель Кармен Гарсия-Бланко, Эрнесто Ролдан-Валадес. Случайная находка - миксома правого желудочка: клинический случай с кратким обзором литеpamypu. REJR 2020; 10(1):245-251. DOI:10.21569/2222-7415-2020-10-1-245-251.

\section{Статья получена: $\quad$ 05.12.19 Статья принята: 21.01 .20}

\section{I}

\section{ntroduction.}

Cardiac myxomas are the most common benign tumours in adults, with an incidence of 0.5 cases per million people per year, $75 \%$ of myxomas are located in the left atrium, whereas 15 to $20 \%$ located in the right atrium, 3 to $4 \%$ located in right ventricle, and the pulmonary artery myxomas are infrequent [1, 2]. Approximately $75 \%$ of myxomas occur in females, between ages 30 to 60 years and in about $7 \%$ of the cases, there is a family history [3-6].

The clinical presentation is very variable; because of this, they are known as "great simulators" of cardiac nosology. However, the primary clinical manifestations are asthenia, weight loss, fever, palpitations, dyspnea, syncope, heart murmur [7]. Myxomas can cause serious complications such as the formation of emboli, which can migrate and cause pulmonary thromboembolism, deep vein thrombosis and arrhythmias [1,8].

For diagnosis, imaging studies enable preoperative localisation of the tumour, as well as the assessment of its size, shape, mobility, the risk of ventricular obstruction, and tumour collapse [5].

\section{Case report.}

A 42 years-old male, with exogenous Cushing's syndrome secondary to corticosteroids for gouty arthritis, and a smoking index of 12.5 packages, entered to the emergency room for abdominal pain in the right hypochondrium. The patient presented other signs and symptoms, which included asthenia, sickness, hypoxia, and deep vein thrombosis (edema, erythema, pain in calves, and present distal pulses) of the right limb, for this last finding, he started therapeutic anticoagulation. Three hours later, the patient developed symptoms of cardiac failure (dyspnea, tachypnea, tachycardia and desaturation). Physical examination revealed jugular engorgement type I, increase in thorax dimensions during respiratory movements; his vesicular murmur had been decreased bilaterally. Laboratory studies revealed hemoglobin $23.3 \mathrm{~g} / \mathrm{dl}$; platelet $89,000 \mathrm{mcL}$ and dimer-D 4,311 ng/dl. Chest X-ray was normal (Fig. 1A). A Doppler ultrasound (DUS) reported deep vein thrombosis (Fig. 1B, C).
Due to the symptoms of cardiac failure and the DUS findings, the patient underwent a CT angiography that reported a mass in the right ventricle that extended beyond the pulmonary valve, protruding beyond the lumen of the pulmonary cone; additionally, a thrombus in the right pulmonary artery and the inferior interlobar artery was detected. The ratio of the diameter of the pulmonary artery $(32 \mathrm{~mm})$ to the aorta $(28 \mathrm{~mm})$ was increased (1.14), a finding associated with pulmonary hypertension (Figure 2).

A supplementary transthoracic echocardiogram (TTE) revealed a dilated right ventricle due to a large mass with heterogeneous echogenicity adhered to the lateral and anterior wall, the mass measured $50 \times 26 \mathrm{~mm}$ in its largest diameters and was obstructing the entrance and exit of the right ventricle. The patient's systolic function was borderline with a tricuspid annular plane systolic excursion (TAPSE) of 17. The occupational mass hindered the opening of the tricuspid valve leading to a mild to moderate insufficiency; the pulmonary arterial systolic pressure was $67 \mathrm{mmHg}$ (Fig. $1 \mathrm{D}$, E).

A cardiac MRI, confirmed the intracardiac mass in the right ventricle measuring $68 \times 27$ $\mathrm{mm}$, with hyperintensity in the T2-weighted imaging and mild enhancement with contrast; there were additional signs of pulmonary hypertension and right pulmonary thromboembolism in segmental branches. (Fig. 3, supplementary video 1).

Supplementary video. Orthogonal plane views of the right ventricular myxoma in CMR.

The patient was stabilised, and treating doctors propounded surgery; however, he did not accept the operation, so the patient was scheduled for follow-up and future planning of surgery.

\section{Discussion.}

Cardiac myxomas are histologically benign tumours; they should be considered as potentially fatal because of their strategic position. Our case presents an infrequent location that is in the right ventricle; this only appears from 3\% to 4\% [2]. Recently, several articles on right ventricular myxomas have been published, one of the related complications is the Carney syndrome, it consists of 


\section{RUSSIAN ELECTRONIC JOURNAL OF RADIOLOGY}

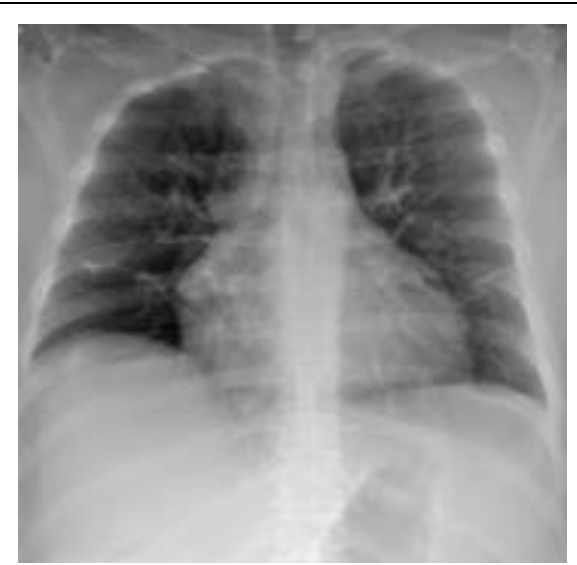

Fig. 1 a (Рис. 1 a)

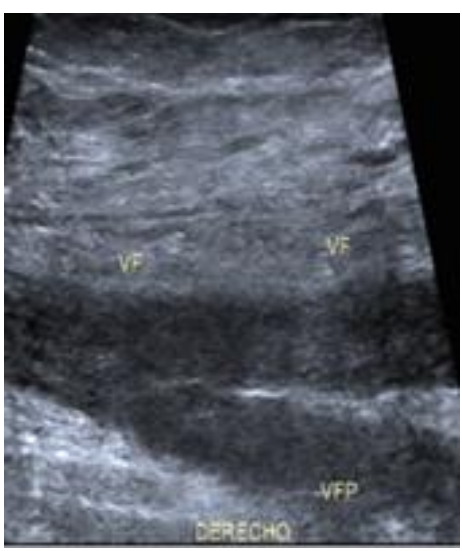

Fig. 1 b (Рис. 1 б)

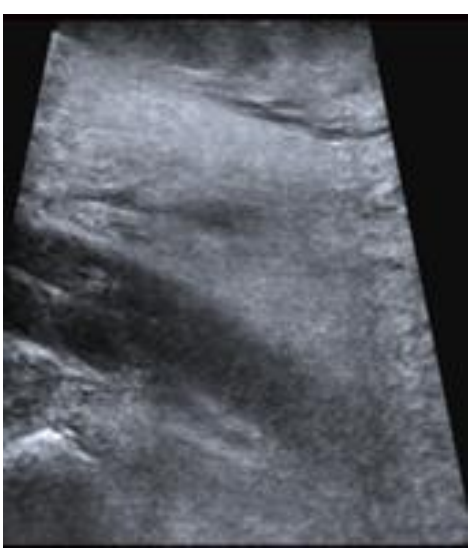

Fig. 1 с (Рис. 1 в)

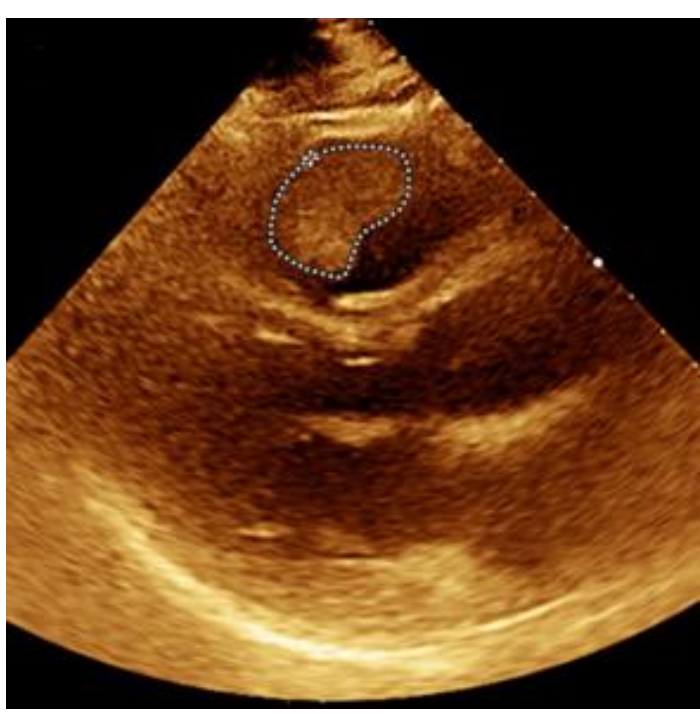

Fig. 1 d (Рис. 1 г)

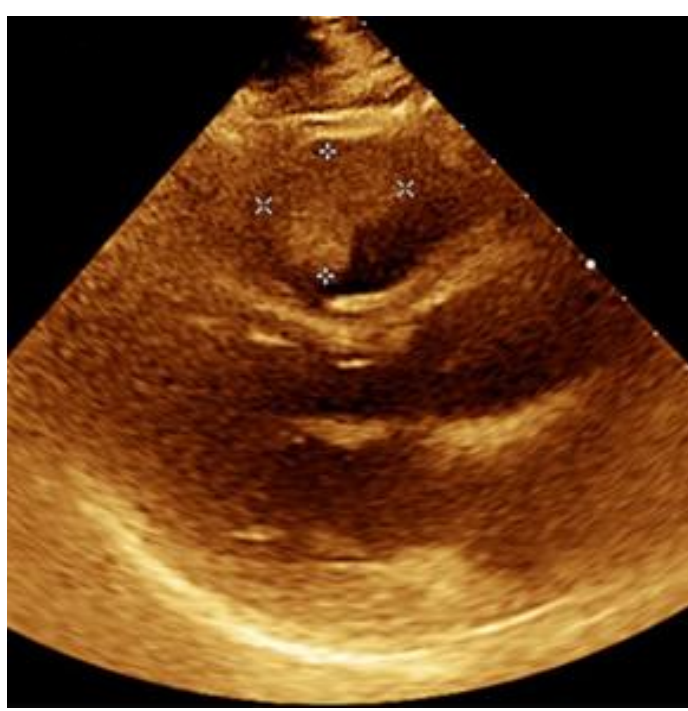

Fig. 1 e (Рис. 1 А)

Fig. 1. Radiology methods.

A - chest-X ray of the patient was reported normal.

B, C - Doppler US depicting the presence of a thrombus at the bifurcation of the femoral vein with extending to the superficial vein. It is evident the absence of blood flow.

D, E - transthoracic echocardiogram (TTE) showing the dimensions of the mass: diameters $50 \times 26 \mathrm{~mm}$ (D), the mass area was $5.57 \mathrm{~cm} 3(\mathrm{E})$.

\section{Рис. 1. Методы лучевого обслелования.}

А - рентгенография органов грудной клетки, без патологических изменений.

Б, В - УЗИ с допплерографией, наличие тромба при разветвлении бедренной вены с распространением на поверхностную вену. Кровоток отсутствует.

Г, Д - трансторакальная эхокардиограмма (TTE), показывающая размеры тромба: диаметр - $50 x 26$ мм (D), площадь - 5,57 см3 (Е). 


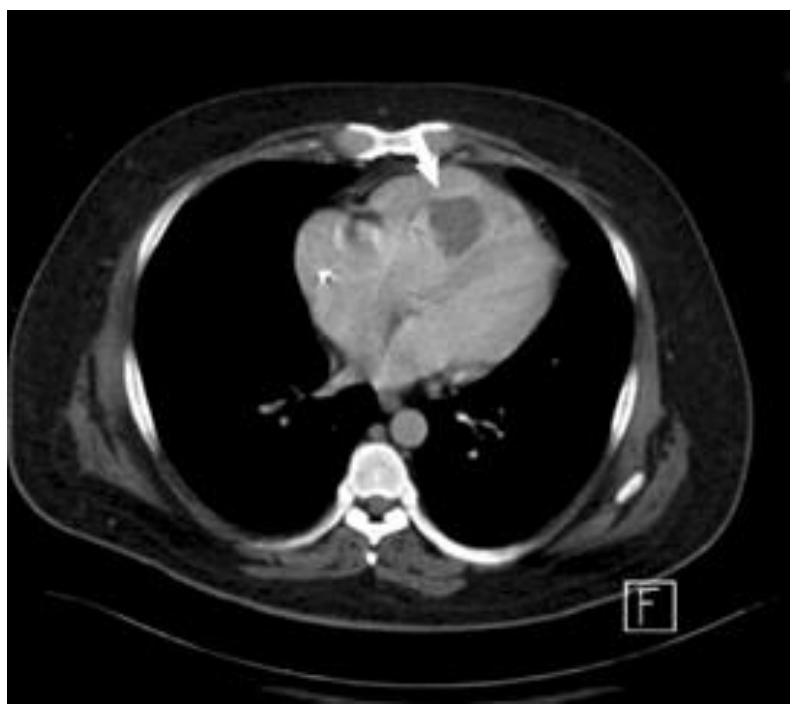

Fig. 2 a (Рис. 2 a)

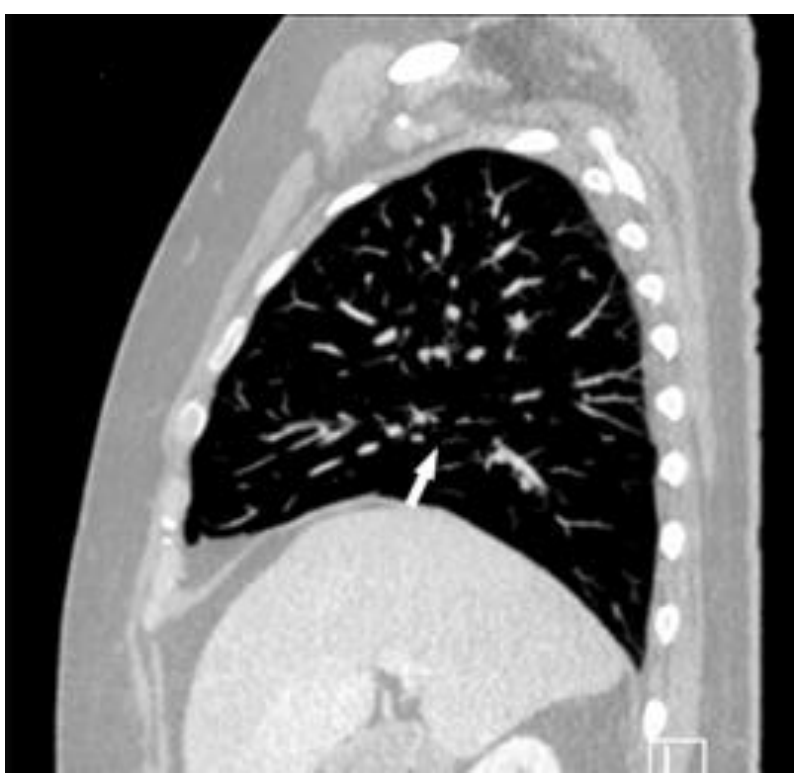

Fig. 2 с (Рис. 2 в)

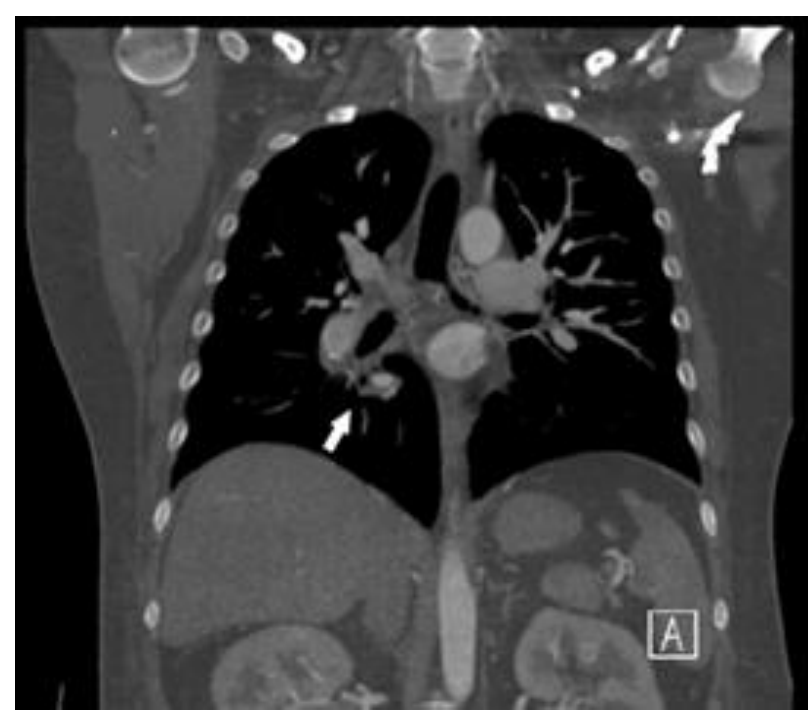

Fig. 2 b (Рис. 2 б)

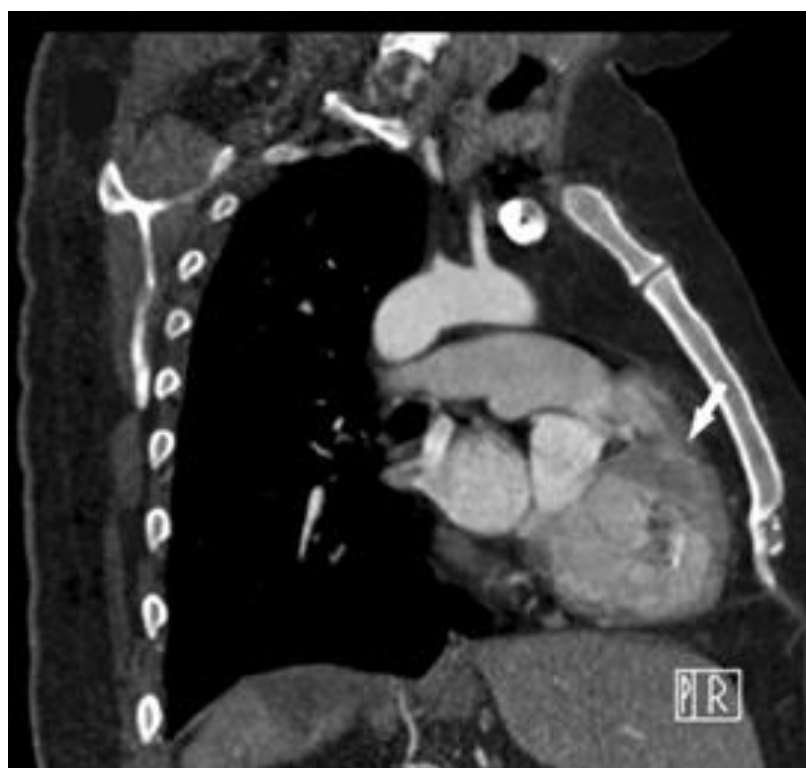

Fig. 2 d (Рис. 2 г)

\section{Fig. 2. CT angiography.}

A - axial view at the level of the ventricular chambers showing an occupational mass within the right ventricle (white arrow).

B - coronal reconstruction revealing a thrombus in the inferior lobular artery.

$\mathrm{C}$ - parasagittal view of the right lung showing a decrease in perihilar vessels consequences of the thrombus.

D - oblique reconstruction depicting the intracardiac mass attached to the lateral wall right ventricle (white arrow).

\section{Рис. 2. КТ ангиография.}

А - аксиальная реконструкция на уровне желудочков: образование, занимающее правый желудочек (белая стрелка).

Б - коронарная реконструкция, тромб в нижне-долевой артерии.

В - сагиттальная реконструкция правого мегкого, показывающий уменьшение перихилярных сосудов в резумьтате тромбоза.

Г - косая реконструкция с изображением внутрисердечного образования, прикрепленного к боковой стенке правого желудочка (белая стрелка). 


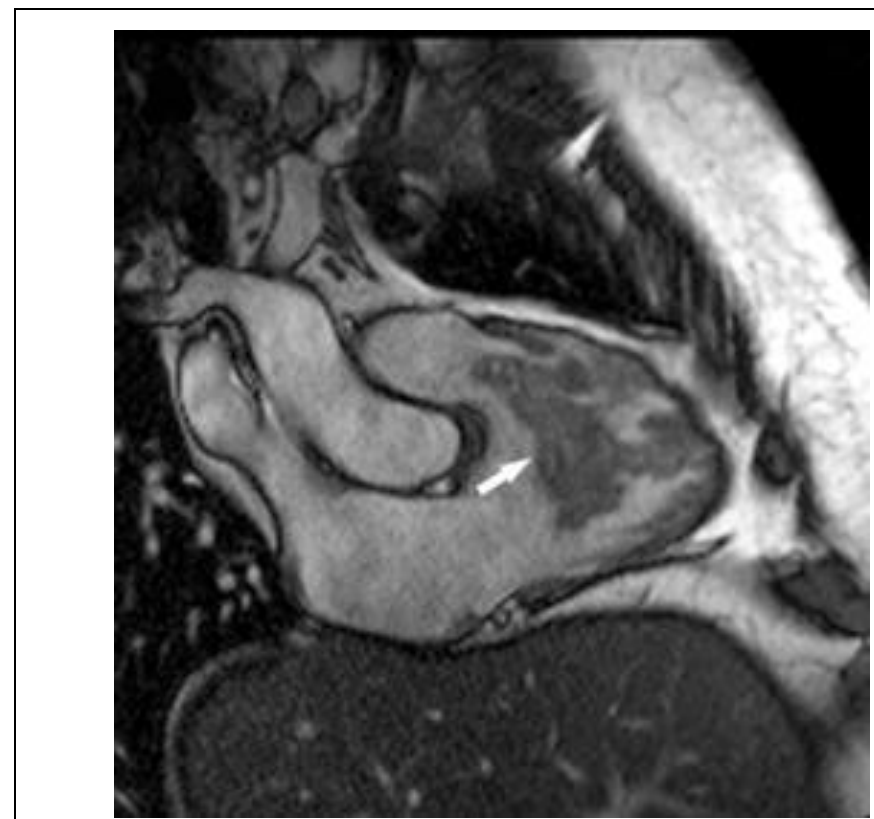

Fig. 3 a (Рис. 3 a)

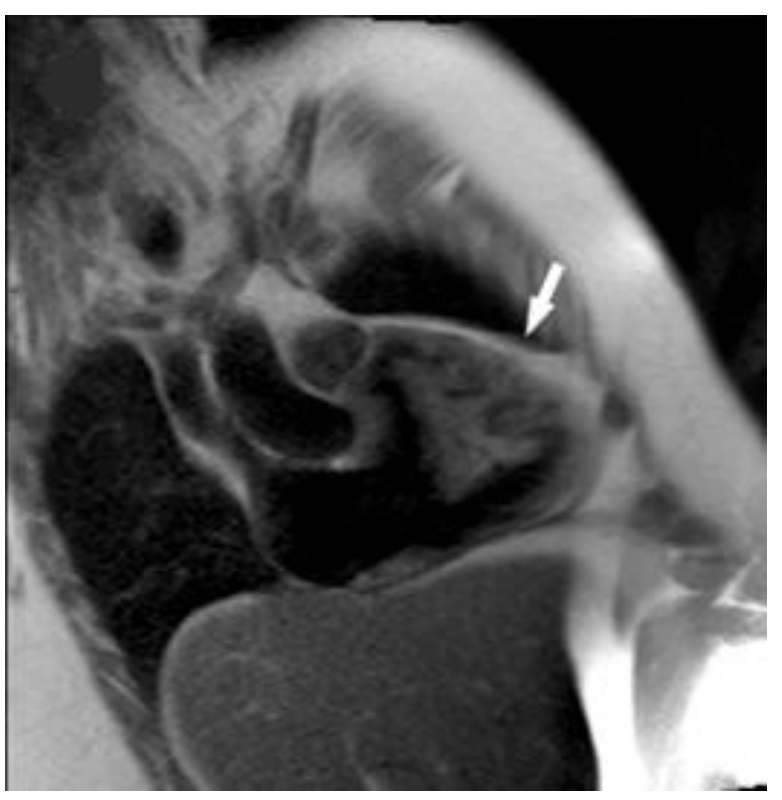

Fig. 3 с (Рис. 3 в)

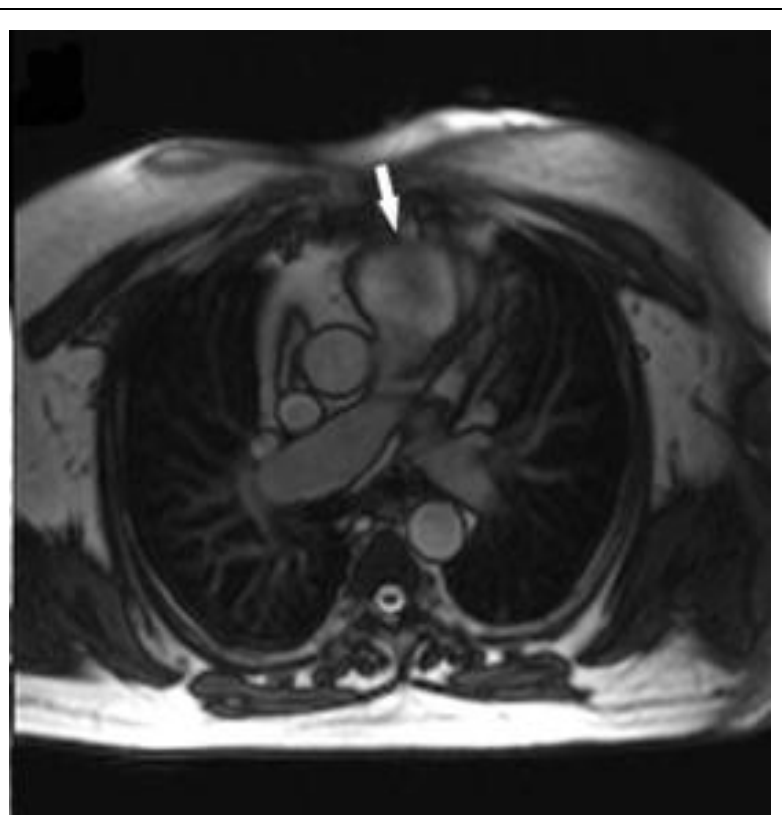

Fig. 3 b (Рис. 3 б)

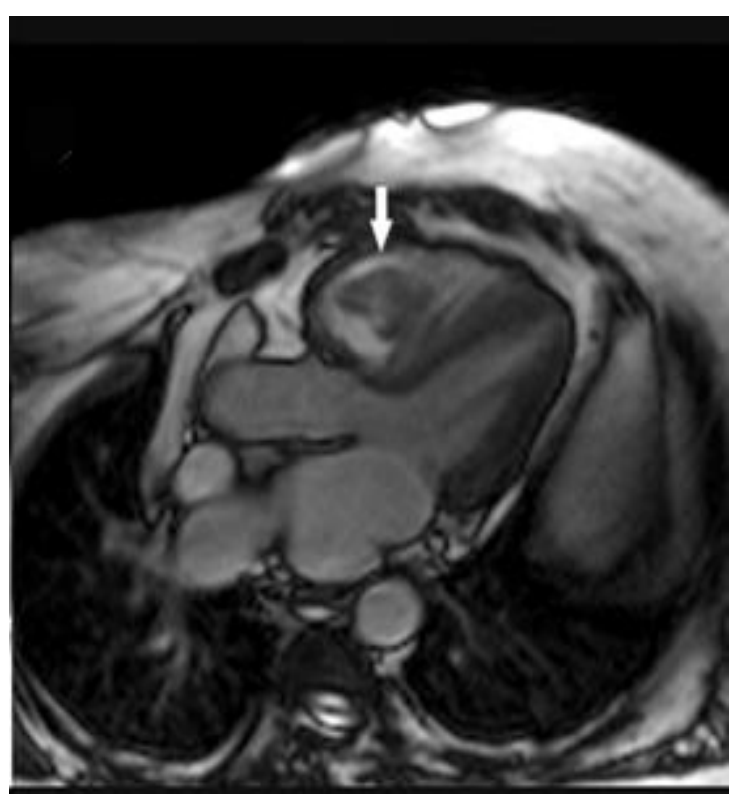

Fig. 3 d (Рис. 3 r)

\section{Fig. 3. Cardiac magnetic resonance (MRI).}

A - sagittal view showing the mass' attachment to the right ventricular wall.

$\mathrm{B}, \mathrm{D}$ - axial views are showing the extension of the mass beyond the pulmonary valve, conditioning obstruction of the right ventricular outflow tract.

$\mathrm{C}$ - oblique reconstruction view showing the mass attached to the lateral wall right ventricle.

Рис. 3. Магнитно-резонансная томография сераца (МРТ).

А - сагиттальная реконструкция, показывающая прикрепление образования к стенке правого желудочка.

Б, Г - аксиальные реконструкции, показывающие распространение образования за пределы клапана мегочной артерии, обусловливающее обструкцию выносящего тракта правого желудочка.

В - косая реконструкция, визуализируется образование, прикрепленное к боковой стенке правого желудочка. 
Table №1. Clinical manifestations and complications of myxomas, modified from Gabe et al. [8]

\section{A. Clinical Manifestations}

Dyspnea

Systemic emboli

Stroke

Transient cerebral attack

Pulmonary embolism

Upper limb embolism

Acute myocardial infarction

Retinal emboli

Angor/ Chest pain

Palpitations

Prolonged febrile syndrome

Endocarditis

Heart murmur

Syncope

Casual find

\section{B. Complications}

Myocardiopathy

Hypertrophy

Thromboembolic processes

Stroke

Pulmonary embolism

Rhythm disorders

Auricular fibrillation

Supraventricular tachycardia

Complete block of the right branch

Left anterior hemiblock

Flow obstruction

Tricuspid stenosis

Vascular lesions

Sudden death cutaneous blemishes, endocrine hyperactivity and myxomas; it present in cardiac and other locations, and the age group has been higher in women between 30 to 60 years of age $[4,5,9]$.

This case is relevant because it is about a 42 years-old male, who enters the emergency department for abdominal pain, then presents data of deep vein thrombosis and heart failure. CT angiography reported pulmonary thromboembolism, and, as an incidental finding, the radiologist reported a right ventricular myxoma, for that reason, the studies were extended to Echocardiogram and MRI. The patient however refused any surgical treatment, so we could not get a biopsy, which is considered the gold standard, then we offered only continuous surveillance management.

The clinical manifestations of cardiac malformations depend on their location, right ventricular tumours are characterised by causing obstruction, embolic processes and constitutional symptoms (fatigue, fever, arthralgia and myalgia), and these would be the classic triad of presentation of these tumours [1, 5, 8] (Table 1).

Early diagnosis and screening are essential since they have an excellent prognosis after surgical excision. Echocardiography is considered the imaging method of choice; it is regarded as the gold standard of the non-invasive techniques be- cause it provides us with data to differentiating from benign and malignant intracardiac tumours. Since echocardiography shows more clearly the presence and extent of cardiac masses, it better distinguishes their location (pericardial, intramural or intracavitary), as well as structural details $[3,5]$. Cardiac magnetic resonance (CMR) has become increasingly valuable to determine cardiac tumours; it is advantageous to differentiate myxomas from other cardiac masses, thrombi and anatomical anomalies, these usually appear as smooth lesions, oval or well defined lobular and tend to be pedunculated and with heterogeneous contrast enhancement [3, 8]. CMR features for myxomas have been previously describing as well as its differential diagnosis with thrombus; for our case the diagnostic imaging features were: pedunculated aspect, the mobility of the lesion, prolapse through the pulmonary valve and heterogeneous enhancement [10] (Table 2).

The treatment of the choice for cardiac myxomas is surgical, preferably of urgent priority, given the high rate of embolic complications. Typically, the echocardiographic follow-up is performed every 6 months in patients who have had a surgical resection to assess whether there is recurrence, up to a period of 10 years, in the case of patients who are stable and do not require emergency surgery, they are monitored every year to 


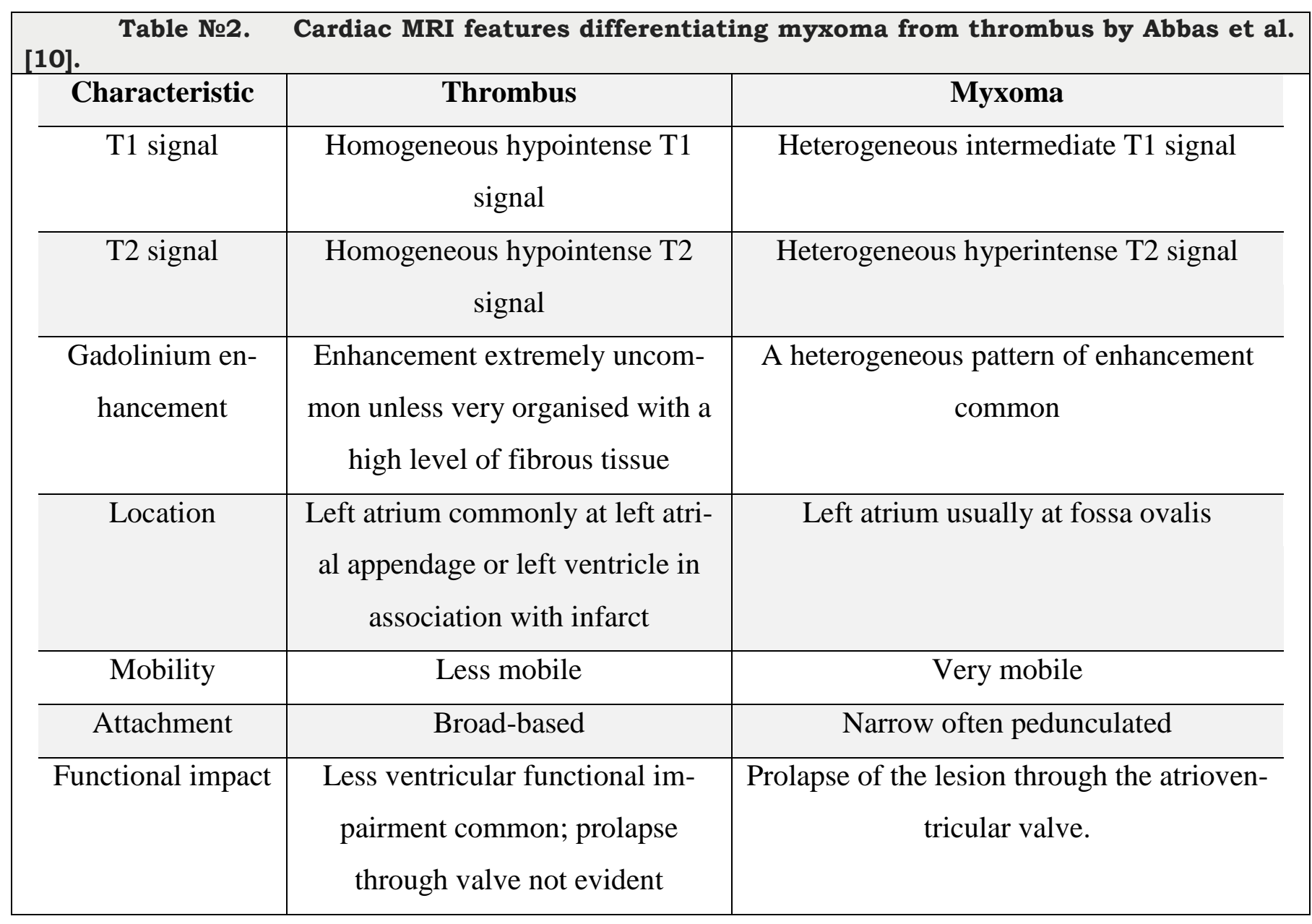

detect changes in the myxoma $[6,8]$.

Conclusion.

Cardiac myxomas are the most common benign tumour in adults, but tumours originating in the right ventricle are unusual. Myxomas are asymptomatic and discovered as an incidental finding. Their medical relevance is due to their potentially lethal complications including

\section{References:}

1. Singh V, Singh SK, Devenraj V, Kumar SJIJoT, Surgery C. Giant right ventricular myxoma obstructing both inflow and outflow tract. 2019.

2. Huang SC, Lee ML, Chen SJ, Wu MZ, Chang CI. Pulmonary artery myxoma as a rare cause of dyspnea for a young female patient. The Journal of thoracic and cardiovascular surgery. 2006;131(5):1179-80.

3. Lone RA, Ahanger AG, Singh S, Mehmood W, Shah S, Lone G, et al. Atrial myxoma: trends in management. International journal of health sciences. 2008;2(2):141-51.

4. Sanjeev OP, Nath SS, Malviya D, Rajput SS. Right atrial myxoma: Unusual location; uncommon association. Annals of cardiac anaesthesia. 2018;21(4):437-9.

5. Gribaa R, Slim M, Kortas C, Kacem S, Ben Salem H, Ouali S, et al. Right ventricular myxoma obstructing the right ventricular outflow tract: a case report. J Med Case Rep. 2014;8:435.

6. Bayramoglu Z, Oral K, Ezelsoy M, Akpinar B. Second recurrence of familial atrial myxomas: mother and daughter simulta- dysrhythmias, pulmonary emboli, and sudden death. Therefore, it is important to make early diagnosis with imaging studies. Follow-up for those who have not undergone surgical resection of the tumour is performed using an echocardiogram every 6 to 12 months.

neously. Cardiovascular journal of Africa. 2019;30:1-4.

7. Gopal AS, Stathopoulos JA, Arora N, Banerjee S, Messineo F. Differential diagnosis of intracavitary tumors obstructing the right ventricular outflow tract. Journal of the American Society of Echocardiography : official publication of the American Society of Echocardiography. 2001;14(9):937-40.

8. Gabe ED, Rodriguez Correa C, Vigliano C, San Martino J, Wisner JN, González P, et al. Mixomas cardiacos: correlación anatomoclinica. Revista Española de Cardiología. 2002;55(05):505-13.

9. Assaf Y, Nasser M, Jneid H, Ott D. Pulmonary Embolism Following Incomplete Surgical Resection of a Right Ventricular Myxoma: A Case Report and Review of the Literature. Cardiology and therapy. 2018;7(1):107-17.

10. Abbas A, Garfath-Cox KA, Brown IW, Shambrook JS, Peebles CR, Harden SP. Cardiac MR assessment of cardiac myxomas. Br J Radiol. 2015;88(1045):20140599. 